\title{
PENYEBAB KRISIS IDENTITAS WARIA
}

\author{
Depilori $^{1}$ \\ Ivan Th. J. Weismann ${ }^{2}$ \\ sttjaffraymakassar@yahoo.co.id
}

\begin{abstract}
ABSTRAK
Penyebab adanya perilaku waria ini tidak dapat dijelaskan dengan sederhana dikarenakan ada banyak faktor penyebab seperti faktor lingkungan dan pola asuh orang tua yang cenderung mendidik dengan kasih sayang yang berlebihan. Sesuai dengan pokok masalah yang ada, maka tujuan penulisan karya ilmiah ini adalah: untuk mengetahui krisis identitas yang dihadapi oleh waria dan mengetahui faktor penyebab krisis identitas waria.

Adapun metode penelitian yang penulis pakai atau gunakan untuk menyusun karya ilmiah ini adalah: Pertama, metode studi kepustakaan adalah metode di mana penulis mengambil atau mengumpulkan data atau informasi dari buku-buku kepustakaan dan dari bahan-bahan penulisan yang lainnya yang ada kaitannya dengan pokok-pokok bahasan dalam penelitian ini untuk memperoleh data yang lebih akurat. Kedua, wawancara adalah tanya jawab dalam suatu pertemuan pribadi dengan maksud untuk mengumpulkan data yang aktual, yang diperlukan dalam penulisan penelitian ini. Ketiga, Observasi adalah pengamatan yang penulis lakukan saat wawancara berlangsung dan pengumpulan data dari informan.

Adapun kesimpulan karya ilmiah ini adalah: Pertama, krisis identitas pada waria disebabkan karena pola asuh orang tua yang salah, yang mendidik anak tidak sesuai gender, anak laki-laki dididik seperti anak perempuan dan sebaliknya. Pemberiaan kasih sayang yang berlebihan, memanjakan anak dengan berdalih anak kesayangan, penolakan-penolakan orang tua yang mengakibatkan anak lari dari rumah dan bergaul dengan teman yang salah, orang tua kurang menyadari pentingnya kerohanian anak, yang dapat dimulai dari rumah. Kedua, seseorang menjadi waria disebabkan karena lingkungan, terlalu banyak bergaul dengan lawan jenis (anak lakilaki teman bergaulnya kebanyakan wanita), berada dalam lingkungan waria dan bergaul dengan waria ikut terlibat dalam kegiatan waria.
\end{abstract}

Kata Kunci: Penyebab, Krisis Identitas, Waria

\footnotetext{
${ }^{1}$ Alumni STT Jaffray tahun 2013

${ }^{2}$ Dosen STT Jaffray
} 


\section{PENDAHULUAN}

\section{Latar Belakang Masalah}

Kejadian 1:27 Allah berfirman bahwa Ia menciptakan manusia itu menurut gambar-Nya, menurut gambar Allah diciptakan-Nya dia; lakilaki dan perempuan. Segala yang diciptakan oleh Allah baik adanya. Ciptaan Allah yang baik itu telah dirusak oleh dosa, dosa mencemari kehidupan manusia dan keturunannya. Salah satu dampak dari dosadosa itu terjadinya penyimpangan seksual. Di mana laki-laki berhubungan seks dengan laki-laki (Homo) dan perempuan berhubungan seks dengan sesama perempuan (Lesbi). Homoseksual bukanlah sesuatu yang baru di zaman ini, jauh sebelumnya homoseksual telah ada di zaman Abraham. Allah menghancurkan kota Sodom dan Gomora karena dosa seksual, mereka saling mencemarkan diri mereka dengan melakukan hubungan seks sesama jenis Kejadian 18-19.

Dosa memang telah memengaruhi kehidupan manusia, dalam perkembangannya manusia telah mengubah apa yang telah Allah ciptakan, yaitu laki-laki mengubah diri menjadi perempuan, merasa diri bukan laki-laki meski memiliki jenis kelamin laki-laki, yang dikenal dengan sebutan Waria (laki-laki yang berpenampilan dan bergaya seperti wanita). Lahirnya perilaku waria tidak lepas dari suatu proses yang panjang atau dorongan yang kuat dari dalam dirinya. Bahwa kondisi fisik mereka tidak sesuai dengan kondisi psikisnya, hal ini menimbulkan konflik psikologis dalam dirinya. Mereka menunjukkan perilaku yang jauh berbeda dari laki-laki normal, tetapi bukan sebagai perempuan yang normal pula. Jika melihat kembali pada firman Tuhan, “...menurut gambar Allah diciptakannyalah dia laki-laki dan perempuan diciptakan-Nya mereka, Kejadian 1:27a. Tentunya mereka yang mengalami konflik identitas ini berada dalam satu masalah yang sulit laki-laki tidak perempuan juga tidak. Namun mereka perlu mendapat perhatian bukan ejekan atau penolakan, sebagai orang percaya harus melihat waria ini lebih jauh, lebih kepada keselamatan jiwa mereka.

Hal yang sama pun diungkapkan oleh Steven Peny. Dalam wawancara langsung "gereja memang belum membahas banyak mengenai waria, namun waria ini jangan kita memandang keberadaan mereka saja, kita perlu melihat lebih jauh yaitu keselamatan jiwa mereka. Karena itulah yang terpenting."3 Penyebab adanya perilaku waria ini tidak dapat dijelaskan dengan sederhana dikarenakan ada banyak faktor penyebab seperti yang dikatakan oleh Randanan Bandaso, "kebanyakan

\footnotetext{
${ }^{3}$ Steven Peny, Wawancara Oleh Penulis, GKII Parousia Makassar, 20 Februari 2013.
} 
berasal dari lingkungan terdekat si waria, dan pola asuh yang salah dari orang tua yang condong pada gender tertentu. Misalnya orang tua yang menginginkan seorang anak perempuan sedangkan anaknya adalah anak laki-laki, dan cenderung mendidik anaknya tersebut layaknya anak perempuan." ${ }^{4}$ Hal seperti ini tentu dapat mempengaruhi kejiwaan si anak dalam pertumbuhannya dimana ia akan mengalami yang namanya konflik identitas. Setiap individu diharapkan dapat memahami perannya sesuai jenis kelamin. Keberhasilan seseorang dalam menentukan identitas jenis kelamin ditentukan oleh berhasil atau tidaknya orang itu dalam menerima dan memahami perilakunya sesuai dengan peran jenis kelaminnya, namun jika ia gagal menerima dan memahami peran jenis kelaminnya maka orang tersebut akan mengalami konflik identitas.

Faktor lain yang mungkin juga dapat menyebabkan seseorang mengalami konflik identitas adalah pengaruh hormon. Randanan Bandaso, mengatakan seorang perempuan dengan jumlah hormon androgen adrenal yang terlalu banyak atau berlebihan yang diproduksi selama dalam kandungan, cenderung menjadi kelaki-lakian. Sebaliknya pada laki-laki yang memiliki hormon perempuan cenderung berperilaku feminim." ${ }^{5}$

Permasalahan yang dihadapi waria ini tidak hanya permasalahan krisis indentitas tetapi juga permasalahan moral. Waria selalu identik dengan homoseksual, yang walaupun tidak semua waria itu homoseksual, namun kebanyakan diantara mereka menjadi waria karena naluri seksnya pada laki-laki, jadi tidak heran jika sering mendengar atau melihat waria-waria yang menjadi pekerja seks komersial, yang sering di jumpai di pinggir jalan kota Makassar (Karebosi, Daya, Maros dan Panaikang). Alasan mereka pun beragam, ada yang karena faktor ekonomi dan biologis. Apapun alasannya, permasalahan waria ini perlu menjadi perhatian gereja maupun keluarga Kristen, karena di antara mereka terdapat juga orang-orang Kristen, perilaku mereka bukan saja melanggar moral dan etika, tetapi dosa yang dapat menjerumuskan mereka ke dalam api kekekalan.

Dengan melihat kenyataan tersebut diatas, penulis merasa perlu untuk menuliskan permasalahan waria tersebut dalam sebuah karya ilmiah dengan judul "Penyebab Krisis Identitas Waria."

\footnotetext{
${ }^{4}$ Randanan Bandaso, "Seksologi," Makassar Terkini 71 (Juni 2009), 100.

${ }^{5}$ Ibid., 105.
} 


\section{Pokok Masalah}

Pokok masalah dalam karya ilmiah ini adalah:

Pertama, bagaimana krisis identitas yang dihadapi oleh waria di Makassar. Kedua, sejauh mana peran keluarga Kristen terhadap krisis identitas waria di Makassar.

\section{Tujuan Penulisan}

Tujuan penulisan karya ilmiah ini adalah:

Pertama, untuk mengetahui penyebab krisis identitas yang dihadapi oleh waria di Makassar. Kedua, untuk mengetahui sejauh mana peran keluarga Kristen terhadap krisis identitas waria di Makassar.

\section{Manfaat Penulisan}

Adapun manfaat penulisan karya ilmiah ini adalah:

Pertama, agar menambah wawasan pembaca, bagaimana peranan keluarga terhadap krisis identitas waria. Kedua, agar menjadi salah satu sumber bacaan mengenai permasalahan waria di Makassar.

\section{Metode Penelitian}

Adapun metode penelitian yang penulis pakai atau gunakan untuk menyusun karya ilmiah ini adalah:

Pertama, metode studi kepustakaan adalah metode di mana penulis mengambil atau mengumpulkan data atau informasi dari buku-buku kepustakaan dan dari bahan-bahan penulisan yang lainnya yang ada kaitannya dengan pokok-pokok bahasan dalam penelitian ini untuk memperoleh data yang lebih akurat. Kedua, wawancara adalah tanya jawab dalam suatu pertemuan pribadi dengan maksud untuk mengumpulkan data yang aktual, yang diperlukan dalam penulisan penelitian ini. Ketiga, Observasi adalah pengamatan yang penulis lakukan saat wawancara berlangsung dan pengumpulan data dari informan.

\section{Batasan Penulisan}

Dalam penulisan diperlukan batasan-batasan yang mempermudah penulis dalam meneliti dan menyusun setiap tulisan. Mengingat luasnya Propensi Sulawesi Selatan maka penulis hanya membatasi penelitian di kota Makassar sebagai objek penelitian. 


\section{Definisi-Definisi}

\section{Krisis}

Menurut Kamus Besar Bahasa Indonesia, "krisis" adalah, "keadaan yang berbahaya, parah sekali, keadaan yang genting atau kemelut, keadaan suram, saat yang menentukan dalam cerita ketika situasi menjadi berbahaya dan keputusan harus diambil." ${ }^{6}$

Steven Fink berkata:

Krisis adalah suatu kondisi di mana helpee menghadapi frustasi dari tujuan-tujuan hidup yang penting atau kekacauan yang amat besar dari siklus hidup mereka dan metode-metode mengatasi berbagai stresor. Istilah krisis biasanya mengarah pada perasaan helpee mengenai ketakutan, kegoncangan, dan dister terhadap kekacauan, bukan kekacauan itu sendiri. Krisis dibatasi dalam waktu, biasanya berakhir tidak lebih dari beberapa minggu. ${ }^{7}$

\section{Identitas}

Kamus Besar Bahasa Indonesia, menjelaskan Identitas adalah, "ciri-ciri atau keadaan khusus seseorang atau jati diri." ${ }^{8}$

Erikson berkata:

Identitas diri adalah mengenal dan menghayati dirinya sebagai pribadi sendiri serta tidak tenggelam dalam peran yang dimainkan, misalnya sebagai anak, teman, pelajar, ataupun teman sejawat. Identifikasi diri muncul ketika anak muda memilih nilai dan orang tempat dia memberikan loyalitasnya, bukan sekadar mengikuti pilihan orang tuanya. Orang yang sedang mencari identitasnya adalah orang yang ingin menentukan siapakah atau apakah yang dia inginkan pada masa mendatang. ${ }^{9}$

\section{Waria}

Kamus Besar Bahasa Indonesia, menjelaskan Waria adalah, "Pria yang bersifat dan bertingkah laku seperti wanita; pria yang mempunyai perasaan sebagai wanita,",10

\footnotetext{
${ }^{6}$ Kamus Besar Bahasa Indonesia, s.v. "krisis."

${ }^{7}$ Steven Fikn, "Definisi krisis" Forum Pembelajar; diakses 07-03-2013; tersedia di http://forumkuliah.wordpress.com/2009/01/20/definisi-krisis/

${ }^{8}$ Kamus Besar Bahasa Indenesia, s.v. "Identitas."

${ }^{9}$ Muhammad Ardi,"Pengertian Identitas Diri" diakses, 07-03-2013, tersedia, www.psychologymania. Com/2012/09/pengertian identitas-diri.html.

${ }^{10}$ Kamus Besar Bahasa Indonesia, s.v. "waria."
} 


\section{METODE PENELITIAN}

\section{Pendekatan Penelitian}

Pendekatan penelitian yang digunakan dalam penelitian ini adalah pendekatan kualitatif.Penelitian kualitatif ini secara spesifik lebih diarahkan pada penggunaan metode studi kasus. Pada dasarnya penelitian dengan jenis studi kasus bertujuan untuk mengetahui tentang sesuatu hal secara mendalam. Maka dalam penelitian ini, peneliti akan mengunakan metode studi kasus untuk mengungkap tentang konsep diri dan faktor yang melatarbelakangi seseorang menjadi waria khususnya permasalahan krisis identitas.

\section{Langkah-Langkah Penelitian}

\section{Tahap Pra Lapangan}

Tahap ini peneliti mengadakan survei pendahuluan yakni dengan mencari subjek sebagai narasumber. Selama proses survei ini peneliti melakukan penjajakan lapangan terhadap latar penelitian, mencari data dan informasi tentang kehidupan waria. Persiapan pra lapangan yang dilakukan peneliti juga dengan menggunakan penelusuran melalui literatur yang berhubungan dengan judul penelitian ini. Dalam tahapan ini peneliti melakukannya selama bulan April-Mai 2013.

\section{Tahap Pekerjaan Lapangan}

Tahap ini peneliti memasuki dan terjun langsung kelapangan untuk mengadakan penelitian dalam rangka mengumpulkan data. Tahap ini dilakukan dalam bulan April-Mei 2013.

\section{Tahapan Analisis Data}

Tahap yang ketiga pada penelitian ini adalah analisis data. Peneliti dalam tahap ini melakukan serangkaian proses analisis data kualitatif sampai pada pengumpulan data yang telah diperoleh sebelumnya. Selain itu peneliti juga menempuh proses trigulasi data yang diperbandingkan dengan teori kepustakaan.

\section{Tahapan Evaluasi dan Pelaporan}

\section{Subjek Penelitian}

Dalam penelitian ini, pengambilan sumber data penelitian mengunakan sampel purposive. Sampel purposive atau sampel sengaja adalah suatu teknik penetapan sampel dengan cara memilih sampel di antara populasi sehingga sampel tersebut dapat mewakili karakteristik 
populasi yang telah dikenal sebelumnya."ll Sampel ini dipilih karena memang menjadi sumber dan kaya dengan informasi tentang fenomena yang ingin diteliti. Pengambilan sampel didasarkan pada pilihan peneliti tentang aspek apa? dan siapa? yang dijadikan fokus pada saat situasi tertentu dan saat ini terus-menerus sepanjang penelitian, dalam penelitian ini yang dijadikan subjek adalah seseorang yang berprofesi sebagai waria yang mengalami krisis identitas.

Adapun ciri dan karateristik yang digunakan yaitu: pertama, seorang laki-laki berprofesi sebagai waria, kedua, berdomisili di kota Makassar, ketiga, terlibat dalam dunia waria, keempat, waria yang beragama Kristen dan kelima, masih aktif sebagai waria. Kriteria ini dipilih untuk memudahkan dan memfokuskan penelitian pada satu daerah.

\section{Metode Pengumpulan Data \\ Wawancara}

Wawancara adalah percakapan dengan maksud tertentu. Percakapan dilakukan oleh dua pihak, yaitu pewawancara dalam hal ini yang mengajukan pertanyaan dan pewawancara yang memberikan jawaban atas pertanyaan yang diajukan. Wawancara dipergunakan untuk mengadakan komunikasi peneliti dengan subjek sehingga diperoleh data-data yang diperlukan. Teknik wawancara ini diperoleh langsung dari subjek penelitian melalui serangkaian tanya jawab dengan pihak-pihak yang terkait langsung dengan pokok permasalahan. Dalam penelitian ini wawancara dilakukan dengan menggunakan pedoman wawancara bebas terpimpin, yaitu cara mengajukan pertanyaan yang dikemukakan bebas, dalam artian pertanyaan tidak terpaku pada pedoman wawancara tentang masalah-masalah pokok dalam penelitian kemudian dapat dikembangkan sesuai dengan kondisi dilapangan.

\section{Observasi}

Observasi sebagai alat untuk mengumpulkan data yang dibutuhkan dalam penelitian ini yaitu dengan cara mengamati, mendengar, dan mencatat hasil wawancara kemudian menganalisisnya. Dalam penelitian ini menggunakan observasi non partisipan dimana peneliti tidak ikut terlibat dalam kegiatan-kegiatan yang subjek lakukan, tetapi observasi dilakukan saat wawancara. Pengamatan dilakukan sesuai dengan pedoman observasi pada saat wawancara berlangsung.

\footnotetext{
${ }^{11}$ Komaruddin, Kamus Riset (Bandung: ANGKASA, 1984), 216.
} 


\section{Teknik Analisis Data}

Analisis data adalah upaya yang dilakukan dengan jalan bekerja dengan data, mengorganisasikan data, memilah-milah menjadi satuan yang dapat dikelola, mencari dan menemukan pola, menemukan apa yang penting dan apa yang dipelajari, dan memutuskan apa yang dapat disampaikan pada orang lain. Dalam penelitian ini teknik analisis data yang digunakan peneliti adalah "Interactive Model" "12 yang terdiri dari tiga langkah yaitu:

\section{Reduksi Data}

Reduksi data yaitu satu proses pemilahan, pemusat perhatian pada penyederhanaan, pengabstrakan dan transformasi data kasar yang muncul dari catatan-catatan tertulis di lapangan.

\section{Penyajian Data}

Data ini tersusun sedemikian rupa sehingga memberikan kemungkinan adanya penarikan kesimpulan dan pengambilan tindakan. Adapun bentuk yang lazim digunakan pada data kualitatif terdahulu adalah dalam bentuk teks naratif.

\section{Penarikan Kesimpulan}

Penelitian ini akan diungkap mengenai makna dari data yang dikumpulkan. Dari data tersebut akan diperoleh kesimpulan yang tentatif, kabur, kaku, dan meragukan sehingga kesimpulan tersebut perlu diverifikasikan. Verifikasi dilakukan dengan melihat kembali reduksi data maupun display data sehingga kesimpulan yang diambil tidak menyimpang.

\section{HASIL PENELITIAN DAN PEMBAHASAN}

\section{Depenelitian Setting Penelitian}

Penelitian ini mengambil latar di propinsi Sulawesi Selatan, kota Makassar secara umum dan khususnya di daerah Daya. Hal ini disebabkan karena Makassar termasuk salah satu kota terbesar di Indonesia yang masyarakatnya sudah menganut kehidupan modern yang memungkinkan terjadinya banyak pertukaran kebudayaan dan gaya hidup yang di bawa dari luar daerah maupun dari luar negeri. Penelitian ini penulis lakukan pada laki-laki yang menjadi waria dan masih aktif sampai sekarang menjadi waria yang tinggal di kota Makassar.

\footnotetext{
${ }^{12}$ Milles dan Huberman, Analisa Data Kualitatif (Jakarta: UI Pess, 1992), 20. 


\section{Depenelitian Subjek Penelitian}

Subjek dalam penelitian ini telah penulis tetapkan sebelumnya dengan kriteria yakni laki-laki yang berprofesi sebagai waria dan masih aktif sebagai waria sampai saat ini. Subjek dalam penelitian ini berjumlah 2 orang laki-laki yang berprofesi sebagai waria dan 1 orang informan. Adapun profil kedua waria tersebut dapat dilihat dalam tabel di bawah ini:

Tabel 1 Data Diri Subjek

\begin{tabular}{|c|l|l|l|}
\hline No & Keterangan & Subjek 1 & Subjek 2 \\
\hline 1 & Nama & Clara & Auriel \\
\hline 2 & Jenis kelamin & Laki-laki & Laki-laki \\
\hline 3 & Usia & 28 tahun & 25 tahun \\
\hline 4 & $\begin{array}{l}\text { Usia Sejak jadi } \\
\text { waria }\end{array}$ & Sejak SMP & 19 tahun \\
\hline 5 & Tempat Tinggal & Daya & Daya \\
\hline 6 & Agama & $\begin{array}{l}\text { Kristen } \\
\text { protestan }\end{array}$ & Kristen Protestan \\
\hline
\end{tabular}

\section{Subjek 1 Clara}

Subjek pertama bernama Clara, Clara adalah seorang waria yang bekerja di salon. Ibunya bekerja sebagai ibu rumah tangga, ibu Clara meninggal saat Clara masih kecil. Dari hasil wawancara diketahui bahwa Clara termasuk orang yang mendapatkan perhatian dan kasih sayang yang lebih dari kelurganya, kemungkinan ini disebabkan karena dia anak terakhir, sosok ayah dimatanya sangat baik peduli pada keluarga, meski ibunya meninggal sejak Clara masih kecil namun sosok seorang ibu dia dapatkan dari kakak pertamanya yang sangat dekat dengan dia bahkan sampai saat ini, kakaknya merupakan tempat yang sangat baik untuk dia curhat mengenai masalahnya karena kakaknya sangat mengerti akan dia dan peduli padanya. Keluarganya pada umumnya sangat baik mereka menerima keadaanya sebagai waria bahkan mereka sering mengundang dia jika ada acara-acara keluarga, kehadirannya dengan berpenampilan seperti wanita bukan menjadi masalah bagi keluarganya bahkan tidak jarang saudara-saudaranya memuji dia dengan mengatakan dia cantik hal ini membuat dia merasa senang.

Clara hanya menyelesaikan pendidikan sampai SMA saja, menurutnya percuma melanjutkan pendidikannya dengan keberadaannya sebagai waria itu hanya akan membuang waktunya saja dia lebih baik bekerja di salon itu lebih menghasilkan. Sekolah hanya tempat pengejekan baginya, bahkan ia sering berkelahi waktu masih duduk di bangku SMP sampai SMA, karena teman-temannya sering 
mengejek dia "bencong" ia tidak segan-segan memukul mereka. Clara termasuk orang banyak bergaul ia memiliki kepercayaan diri yang cukup tinggi meskipun dia seorang waria, karena ia tidak pernah mengalami penolakan dari keluarganya. Kerena masalah-masalah yang sering dihadapinya di dunia pendidikan membuat Clara enggan melanjutkan pendidikannya kejenjang yang lebih tinggi.

Clara menjadi waria semenjak kelas $4 \mathrm{SD}$, perasaan menyukai pria sudah ada, ia tidak merasa dirinya seorang laki-laki, namun berpenampilan seperti wanita secara utuh sejak SMA. Clara sempat merasa stres saat mengetahui ia seorang waria, tetapi ia tidak dapat membohongi dirinya sendiri kalau ia sama sekali tidak memiliki perasaan suka pada wanita. Namun menurutnya ia menjadi waria secara alami tanpa adanya suatu kejadian yang akhirnya membuat dia menjadi waria atau mengalami pelecehan seksual, menurutnya perasaan itu muncul dalam hati dengan sendirinya. Selama menjadi waria Clara sudah terlibat dalam dunia gelap waria, seperti dunia pelacuran bahkan ia mengaku pernah melakukan hubungan seks dengan pacarnya yang adalah pria seperti yang diungkapkannya dalam wawancara "Yaa...ampun kalau itu saya jujur ya kalau masalah itu yaaa gak bisa dihitung hampir setiap hari sama pacarku." ${ }^{33}$ Namun tidak pernah memberikan pelayanan seks pada wanita.

Clara sangat menghormati orang lain, namun saat dimana dia tidak dihormati Clara juga tidak menghormati orang itu, Clara juga termasuk orang yang jujur karena dari keluarga sudah mengajarkan masalah kejujuran itu, tetapi menurutnya ia pernah bohong juga pada pacarnya. Sebagai makhluk ciptaan Tuhan yang mulia Clara mengaku ia sangat menghormati dirinya, meski tidak pernah pergi kegereja sejak jadi waria ia merasa bahwa ia tetap memiliki iman hanya dia tidak pergi kegereja. Clara juga memiliki pengharapan terhadap dirinya seperti keinginan untuk sukses dibidang persalonan, ia juga memiliki perasaan untuk kembali menjadi laki-laki namun ia tidak ingin hanya berubah penampilan saja, keinginannya Tuhan dapat mengubah perasaannya juga, karena percuma jika berubah penampilan, tetapi perasaan masih saja wanita. Dengan keadaannya sebagai seorang waria Clara sangat merasa ia mengalami masalah identitasnya, seperti dalam hal pembuatan KTP. Clara saat ini tinggal di daerah Daya, tinggal disebuah rumah kontrakan,yang sekaligus merupakan tempat usaha salonnya. Lingkungan tempat tinggalnya sebagian besar merupakan penganut agama Islam dan lingkungan itu kebanyakan tempat kos-kosan waria. Faktor itu juga salah satu membuat ia tidak lagi bergereja dan sulit

\footnotetext{
${ }^{13}$ Clara, Wawancara Oleh Penulis, Makassar, Sulawesi Selatan, 31 Mai 2013.
} 
baginya untuk keluar dari dunia waria, meski lingkungan sekitarnya menerima keberadaanya dengan teman-temannya namun tidak jarang mereka mendapat penolakan dari ormas-ormas.

\section{Faktor Yang Melatarbelakangi Subjek Clara Menjadi Waria}

Untuk mengetahui faktor-faktor yang melatarbelakangi subjek Clara menjadi waria maka penulis mengajukan beberapa pertanyaan yang berhubungan dengan hal-hal tersebut. Berdasarkan hasil wawancara maka penulis mencoba memaparkan faktor apa yang menyebabkan subjek Clara menjadi waria.

Pertama, faktor gen/ bawaan sejak lahir, seperti pengakuan subjek bahwa ia merasa memiliki perasaan wanita semenjak SD kelas 4, dan mulai menggunakan pakaian wanita semenjak SMA, berikut pernyataan subjek "aku merasa mulai suka sama cowok sejak kelas 4 SD, tetapi aku mulai berpenampilan wanita sejak SMA."

Kedua, faktor keluarga, sebagai anak terakhir Clara merasa ia mendapatkan kasih sayang yang lebih dari saudara-saudaranya, berikut pernyataannya "yaaa,, gak semua bagi Clara. Ada juga dari saudara-saudara yang memberi kasih sayang, saya selalu mendapatkan kehangatan, bahkan saya rasa lebih karena saya anak terakhir."

Penerimaan Clara dimata keluarganya sebagai waria membuat ia terus hidup sebagai waria, merasa diterima sebagai waria dan memiliki perasaan wanita maka hal itu membuat Clara terus hidup sebagai seorang waria.

Ketiga, faktor lingkungan, semenjak menjadi waria, Clara memiliki teman bergaul sesama waria, lingkungan kontrakannya kebanyakan waria, masyarakat setempat juga tidak mempermasalahkan keberadaan mereka dilingkungan itu.

\section{Peran Keluarga Terhadap Kasus Clara}

Dengan melihat kasus yang terjadi pada subjek Clara dan faktor yang melatarbelakangi subjek menjadi waria, maka keluarga harus mengambil perannya sebagai orang terdekat dengan subjek untuk melakukan pencegahan sejak dini agar anaknya tidak terjebak dan terlibat dalam dunia waria. Adapun peran keluarga yang harus dilakukan,

Pertama, orang tua harus memberikan kasih sayang pada anakanaknya secara utuh, orang tua perlu memahami apa yang menjadi bahasa kasih anak-anak mereka karena setiap anak pasti memiliki bahasa kasihnya masing-masing, seperti: kebersamaan atau waktu yang berkualitas, pemberian hadiah, pemberian pujian atau afirmasi, 
pelayanan, sentuhan atau kehangatan. kasus yang dihadapi Clara, ia tidak mendapatkan kasih sayang yang cukup dari ibunya namun sosok ibu ia hanya terima dari saudara tertuanya. Karena merupakan anak terakhir Clara menjadi anak yang manja.

Kasih sayang dari orang tua sangat dibutuhkan oleh seorang anak, dengan kasih sayang yang mereka dapat dari orang tua itu sangat berpengaruh dalam kehidupan anak mereka, seorang anak yang mendapatkan kasih sayang dari orang tuanya akan menjadi anak yang dapat diatur oleh orang tuanya sedangkan seorang anak yang tidak mendapatkan kasih sayang dari orang tuanya dari kecil akan lebih memilih untuk mendapatkan kasih sayang dari orang lain. Itulah sebabnya perilaku waria itu muncul, mereka mencari kasih sayang dari orang yang mereka anggap mengerti keadaan mereka, sehingga mereka pun terjerumus dalam homoseksual, penyuka sesama jenis. Mereka tidak mendapat kasih sayang yang utuh, sehingga mereka mencari kasih sayang itu diluar. Bill Sanders mengatakan, "setiap pemuda perlu mengetahui bahwa mereka akan memperoleh kasih sayang yang utuh dari ayah dan ibu mereka secara terus menerus." ${ }^{14}$

Kedua, orang tua harus menanamkan disiplin dalam keluarga, disiplin dalam bentuk aturan-aturan yang mengarahkan anak pada halhal yang benar menjadi seorang yang berkarakter, disiplin yang diberikan membuat seorang anak tidak akan melakukan apa saja sesuai dengan keinginannya, namun dengan adanya disiplin dalam keluarga seorang anak akan tahu membedakan mana yang benar dan mana yang salah. Clara termasuk anak yang terlalu dimanja oleh saudaranya dan tidak memberikan suatu pemahaman yang benar mengenai mana yang salah dan mana yang benar padanya, dengan menerima Clara sebagai seorang waria dan membiarkan dia bertumbuh dalam kewariaannya.

Disiplin memiliki hubungan dengan keteraturan, hal ini yang harus dimiliki setiap orang agar dapat menjalani hidup dengan baik dan teratur. Dalam hubungannya dengan anak disiplin merupakan suatu hubungan belajar dan mengajar diantara orang tua dan anak, orang tua mendisiplin anak, dan anak bertanggung jawab terhadap perilakunya sendiri." ${ }^{15}$ Orang tua perlu memberikan pemahaman yang jelas pada anak mengenai disiplin ini, apa yang boleh dan tidak boleh dilakukan. Hal ini tidak mudah memang namun harus dilakukan dengan kesabaran, ketegasan, kelemahlembutan, dan mengajarkanya secara teratur. Disiplin juga dapat menjauhkan seseorang dari kemalasan atau berbuat terlalu sedikit, sanggup mengendalikan emosi sendiri, sanggup

\footnotetext{
${ }^{14}$ Bill Sanders, Dari Remaja Untuk Orang Tua (Bandung: Yayasan Kalam Hidup, 1995), 42

${ }^{15}$ Mary Go Setiawani, Menerobos Dunia Anak (Bandung: Kalam Hidup 2000), 32. 
mengendalikan nafsu, dan dapat mengatur diri serta waktu." 16 Pembentukan karakter pada anak memang sangat penting, karena karakter yang baik pada anak akan menentukan bagaimana ia bersikap, bertindak dan mengambil keputusan dalam menghadapi suatu masalah. karakter yang baik pada anak akan menghasilkan pribadi yang baik pula. Karena itu orang tua perlu membentuk karakter anaknya sejak dini dengan memperhatikan apa yang menjadi kebutuhan mereka, dan mendisiplinkan mereka dengan kasih.

Ketiga, orang tua perlu memberikan teladan kerohanian pada anakanaknya. Dimulai dengan ibadah dalam keluarga, berdoa bersama, pergi kegereja, dalam keluarga Clara mereka memang cukup baik, namun ia mengaku bahwa orang tuanya kurang memberikan teladan kerohanian bagi dia dan saudara-saudaranya. Seperti jawaban yang diberikan pada penulis dalam wawancara, "ada sih,, tetapi tidak terlalu, palingan hanya suruh pergi ibadah aja,, yaa ada juga sih mereka pergi ibadah"l7 teladan rohani sangat mempengaruhi iman bagi anak-anak dalam pertumbuhan mereka.

Keempat, orang tua perlu mengajarkan kekudusan bagi anak-anak sejak dini. Kekudusan akan mengarahkan anak pada permasalahan moral juga. Bagaimana seorang anak dapat menghargai dirinya sebagai ciptaan Tuhan yang mulia tidak akan mengubah apa yang Tuhan ciptakan, mengajarkan kekudusan tidak terlepas dari permasalahan seks, orang tua perlu memberikan penjelasan yang benar tentang seks, sehingga anak bisa mengerti dan menjaga anggota tubuhnya dengan baik.

Kelima, orang tua harus mengarahkan anak-anaknya sesuai gender, jika anaknya laki-laki maka orang tua harus mendidiknya selayaknya anak laki-laki pada umumnya, dalam hal berpakaian, pemilihan jenis permainan, dan teman bergaul. Begitu juga sebaliknya jika anaknya perempuan maka orang tua harus mendidik anaknya seperti anak perempuan pada umumnya, berpakaiaan seperti anak perempuan, pemilihan jenis mainan, dan teman bergaul.

\section{Subjek 2 Auriel}

Subjek kedua dalam penelitian ini adalah Auriel, ia tinggal di Daya dan bekerja di salon. Ayahnya hanya bekerja sebagai petani, ibunya hanya seorang ibu rumah tangga, di mata Auriel sosok seorang ayah baik mengharapkan anak-anaknya bahagia dan sukses, sosok ibunya juga sama, ibunya seorang penyayang terlebih pada anak-anaknya, apalagi pada dirinya mungkin karena dia anak terakhir dan saudara-saudaranya

\footnotetext{
${ }^{16}$ Linda dan Richerd Eyre, Mengajarkan Nilai-Nilai Kepada Anak (Jakarta: Gramedia Pustaka Utama, 1999), 64.

17 Clara, Wawancara Oleh Penulis, Makassar Sulawesi Selatan, 31 Mai 2013.
} 
sudah dewasa semua, bahkan ketika masih tinggal bersama orang tua Auriel tidak pernah di minta untuk bekerja berat paling hanya disuruh memasak dan mencuci piring. Dalam keluarga orang yang paling dekat dengan Auriel adalah mamanya, dalam rumah mereka tidak memiliki aturan, prinsipnya masing-masing jaga diri. Dalam pemberian kasih sayang Auriel mengaku cukup mendapat kasih sayang, hanya kurang dengan keadaannya sebagai waria, ketika mendapat prestasi di sekolah Auriel juga sering mendapat pujian dari orang tuanya. Semenjak kecil sampai SMA Auriel selalu bersama orang tuanya bahkan sampai tidur bersama mereka juga ia termasuk anak yang manja dan kebanyakan teman bermainnya perempuan. Orang tua Auriel tidak mengetahui kalau dia seorang waria sampai saat ini, ada beberapa saudaranya yang mengetahui dia seorang waria, tetapi mereka tetap menerima dia. Namun menurutnya bagi orang tuanya jika mereka melihat penampilannya sebagai waria, orang tua sangat menentangnya karena itu merupakan aib bagi keluarganya karena hanya dia yang waria dalam keluarganya. Pengharapannya ialah orang tua bisa menerima dia apa adanya.

Dalam keluarganya mereka memiliki disiplin keluarga khususnya masalah waktu, penanaman disiplin dan masalah menghormati sangat di tanamkan. Meskipun dalam keluarga mereka tidak memiliki ibadah keluarga namun orang tua tetap mendorong anak-anaknya untuk beribadah, Auriel termasuk orang yang rajin beribadah sebelum menjadi waria namun semenjak 2008 ia tidak lagi pernah pergi kegereja namun ia tetap berdoa sampai saat ini. Auriel tetap merasa memiliki iman hanya yang membedakannya saat ini ia tidak lagi pergi kegereja. Perasaannya saat ini terhadap Tuhan galau seperti yang diungkapkannya saat wawancara "galau sih... kenapa gak galau? Banyak sekali dosa coba. Yang menurut kita gak mampu dijalani” ${ }^{18}$ Dalam keluarga mereka kurang mendapatkan kehangatan, seperti kebersamaan dimeja makan dan yang lainnya.

Auriel menjadi waria semenjak 2008, namun sebelumnya ia sudah merasa memiliki perasaan sebagai wanita sejak umur 5 tahun. Saat menjadi seorang waria ia merasa bahagia sekali, Auriel menyadari ada banyak tantangan sebelum ia merubah dirinya mulai dari orang tua yang tidak setuju ia menjadi waria, perasaan yang tertekan dari orang tua, dimana ia merasa dirinya wanita namun tidak bisa menunjukkannya. Menurutnya ia menjadi waria secara alami perasaan yang muncul dalam hatinya, ia tidak memiliki pengalaman dimasa lalu yang akhirnya membuat dia menjadi waria atau pengalaman pelecehan seksual tidak

\footnotetext{
${ }^{18}$ Auriel, Wawancara Oleh Penulis, Makassar Sulawesi Selatan, O1 Juni 2013.
} 
pernah ia alami. Auriel juga pernah terlibat dalam dunia gelap waria, melakukan hubungan seks dengan pria.

Auriel termasuk orang yang kurang jujur, meskipun dalam keluarga ada mengajarkan kejujuran. Ia juga kurang menghormati orang, tergantung orang itu apa orang itu menghormati dia atau tidak. Selama menjalani hidup sebagai waria Auriel mengakui ia tidak pernah bergereja, sebelum menjadi waria dia sangat rajin pergi kegereja. Meskipun demikian ia mengaku bahwa ia masih tetap berdoa sampai saat ini meski jarang-jarang, imannya pada Tuhan masih ada dalam hatinya hanya ia merasa malu pergi kegereja dengan penampilannya sebagai waria. Dengan keadaannya sebagai waria Auriel merasa dia tidak menghargai dirinya sebagai makhluk ciptaan Tuhan yang mulia karena ia mengubah apa yang sudah Tuhan ciptakan, namun ia membenarkan diri dengan mengatakan bahwa ia tidak bisa membohongi perasaannya juga. Dalam hidupnya Auriel memiliki harapan akan masa depannya seperti sukses dalam usaha persalonan, ia juga memiliki pengharapan untuk menjadi laki-laki kembali, dan yang sangat diharapkannya saat ini ialah keluarganya dapat menerima keadaannya sebagai waria karena keluarga belum mengakui keadaannya.

Auriel saat ini tinggal di Daya, ia kost bersama beberapa teman warianya. Salon tempat ia bekerja tidak jauh dari kostnya. Lingkungan sekitar kost kebanyakan waria dan masyarakatnya sebagian besar memeluk agama Islam. Lingkungan dimana Auriel berada sangat menghargai dan menghormati keberadaannya, meski ada beberapa juga yang menolak. Dengan lingkungan yang kebanyakan waria oto/matis Auriel bergaul dengan sesama waria juga keadaan itu justru tidak akan menolong dia untuk berubah malah akan semakin terjerumus dalam dunia waria, ditambah lagi lingkungan yang tidak seiman dengan dia tentunya iman Auriel tidak dapat bertumbuh dengan baik.

\section{Faktor Yang Melatarbelakangi Subjek Auriel Menjadi Waria}

Untuk mengetahui faktor-faktor yang melatarbelakangi subjek Auriel menjadi waria maka penulis mengajukan beberapa pertanyaan yang berhubungan dengan hal-hal tersebut. Berdasarkan hasil wawancara maka penulis mencoba memaparkan faktor apa yang menyebabkan subjek Auriel menjadi waria.

Pertama, faktor gen. Ini sesuai dengan pernyataannya yang mengatakan bahwa ia merasa memiliki perasaan wanita sejak usia 5 tahun, meski baru tahun 2008 ia berpenampilan seperti wanita, tetapi perasaannya sebagai wanita suadah ada sejak kecil.

Kedua, faktor pola asuh orang tua, selain faktor gen yang ada pada subjek Auriel, pola asuh orang tua juga turut membentuk perilakunya 
sebagai waria, ia mengaku bahwa semenjak kecil menjadi anak yang manja, tidak pernah mengerjakan pekerjaan yang berat seperti saudara laki-lakinya yang lain, ia juga sering dibelikan mainan boneka seperti yang diungkapkannya saat wawancara,

"Iyalah waktu masih tinggal sama orang tua, tidur sama orang tua sampai SMA, saya termasuk anak yang manja, gak pernah dikasih pekerjaan berat, paling disuruh masak, cuci piring, bahkan aku punya teman bergaul itu perempuan semua."

Ketiga, faktor lingkungan, melihat masa kecil subjek Auriel, ia bergaul dan lebih banyak memiliki teman wanita dari pada teman pria, hal ini sangat mempengaruhi perilaku subjek yang pada dasarnya memiliki jiwa seorang wanita, selain itu subjek juga saat ini bergaul dilingkungan yang kebanyakan adalah sesama waria.

\section{Peran Keluarga Terhadap Kasus Auriel}

Dengan melihat kasus yang terjadi pada subjek Auriel dan faktor yang melatarbelakangi subjek menjadi waria, maka keluarga perlu mengambil perannya sebagai orang terdekat dengan subjek untuk melakukan pencegahan sejak dini agar anaknya tidak terjebak dan terlibat dalam dunia waria. Adapun peran keluarga yang harus dilakukan:

Pertama, orang tua harus memberikan kasih sayang, kasih sayang dari orang tua sangat dibutuhkan anak-anak dalam pertumbuhan mereka. Ekspresi cinta dari orang tua yang lahir dengan ketulusan tanpa adanya pemaksaan, seorang anak akan mendapat teladan kasih tanpa pamrih, orang tua perlu menyadari bahwa kebutuhan emosi seorang anak adalah cinta kasih yang tulus dan murni dari orang tuanya. Kasih sayang dapat diwujudkan dalam bentuk, pemberian hadiah, menyediakan waktu yang cukup bagi anak-anak, memberikan pujian atas prestasi mereka, pelayanan bagi mereka, dan kehangatan atau sentuhan fisik melalui pelukan, belaian dan ciuman. Sentuhan fisik merupakan satu dasar bahasa kasih, yang mana orang tua harus menggunakannya disaat yang tepat, di tempat dan dengan cara yang tepat.

Kedua, orang tua harus memberikan teladan kerohanian, anakanak adalah individu yang suka meniru sesuatu yang mereka lihat, karena itu orang tua harus memberikan teladan bagi anak-anaknya khusus dalam hal kerohanian mereka, iman seseorang terbentuk dimulai dari keluarganya. Dalam keluarga orang tua harus mengajarkan anak- 
anak untuk berdoa, mendorong mereka beribadah, melakukan ibadah keluarga, dan berdoa bersama.

Ketiga, orang tua harus mengajarkan kekudusan bagi anak-anak sejak dini. Kekudusan akan mengarahkan anak pada permasalahan moral juga. Bagaimana seorang anak dapat menghargai dirinya sebagai ciptaan Tuhan yang mulia tidak akan mengubah apa yang Tuhan ciptakan, mengajarkan kekudusan tidak terlepas dari permasalahan seks, orang tua perlu memberikan penjelasan yang benar tentang seks, sehingga anak bisa mengerti dan menjaga anggota tubuhnya dengan baik.

Kempat, orang tua harus mengarahkan anak-anaknya sesuai gender, jika anaknya laki-laki maka orang tua harus mendidiknya selayaknya anak laki-laki pada umumnya, baik dalam hal berpakaian, pemilihan jenis permainan, dan teman bergaul. Begitu juga sebaliknya jika anaknya perempuan maka orang tua harus mendidik anaknya sesuai anak-anak perempuan pada umumnya, berpakaian seperti anak perempuan, pemilihan jenis mainan, dan teman bergaul.

Kelima, orang tua perlu menanamkan disiplin dalam keluarga, disiplin dalam bentuk aturan-aturan yang mengarahkan anak pada halhal yang benar menjadi seorang yang berkarakter, disiplin yang diberikan membuat seorang anak tidak akan melakukan apa saja sesuai dengan keinginannnya, namun dengan adanya disiplin dalam keluarga seorang anak akan tahu membedakan mana yang benar dan mana yang salah. Aurel termasuk anak yang terlalu dimanja oleh orang tuanya, namun tidak memberikan suatu pemahaman yang benar mengenai mana yang salah dan mana yang benar padanya. 


\section{PENUTUP}

\section{Kesimpulan}

Sebagai penutup dari penelitian ini maka penulis akan memberikan beberapa kesimpulan:

Pertama, krisis identitas pada waria disebabkan karena pola asuh orang tua yang salah, yang mendidik anak tidak sesuai gender, anak lakilaki dididik seperti anak perempuan dan sebaliknya. Pemberiaan kasih sayang yang berlebihan, memanjakan anak dengan berdalih anak kesayangan, penolakan-penolakan orang tua yang mengakibatkan anak lari dari rumah dan bergaul dengan teman yang salah, orang tua kurang menyadari pentingnya kerohanian anak, yang dapat dimulai dari rumah.

Kedua, seseorang menjadi waria disebabkan karena lingkungan, terlalu banyak bergaul dengan lawan jenis (anak laki-laki teman bergaulnya kebanyakan wanita), berada dalam lingkungan waria dan bergaul dengan waria ikut terlibat dalam kegiatan waria. Lingkungan yang tidak mendukung, membiarkan perilaku menyimpang bertumbuh tanpa adanya suatu upaya menolong, tidak adanya keteladan iman dari lingkungan sekitar. 


\section{KEPUSTAKAAN}

\section{Alkitab dan Kamus}

Alkitab. Lembaga Alkitab Indonesia, 2006.

Tim Penyusun Kamus Pusat Pembinaan dan Pengembangan Bahasa.

Kamus Besar Bahasa Indonesia. Jakarta Balai Pustaka, 1994.

Buku-Buku

Komaruddin, Kamus Riset. Bandung: ANGKASA, 1984.Lexy,J. Meleong. Metodologi Penelitian Kualitatif . Bandung: Rosdakarya, 2007.

Linda dan Eyre,Richerd. Mengajarkan Nilai-Nilai Kepada Anak .Jakarta: Gramedia Pustaka Utama, 1999.

Mery Go Setiawani, Go Mery. Menerobos Dunia Anak. Bandung: Kalaum Hidup 2000.

Milles dan Huberman. Analisa data Kulitatif. Jakarta: UI Press, 1992.

Narramore, M. Clyde .Menolong Anak-Anak Anda Bertumbuh Dalam Iman. Bandung: Kalam Hidup, 1961.

Sanders, Bill. Dari Remaja Untuk Orang Tua.Bandung: Yayasan Kalam Hidup, 1995.

Majalah

Bandaso, Randanan. “Seksologi,” Makassar Terkini 7, 1 Juni 2009.

Artikel di Internet

Ardi Muhammad"Pengertian Identitas Diri" diakses, 07-03-2013, tersedia, www.psychologymania. Com/2012/09/pengertian identitasdiri.html.

Fikn, Steven. "Definisi krisis" Forum Pembelajar; diakses 07-03-2013; tersedia di http://forumkuliah.wordpress.com/2009/01/20/definisi-krisis/

Wawancara

Auriel, Wawancara Oleh Penulis, Makassar Sulawesi Selatan, 01 Juni 2013. Clara, Wawancara Oleh Penulis, Makassar, Sulawesi Selatan, 31Mai 2013.

Peny, Steven. Wawancara Oleh Penulis. Makassar: GKII Parousia Makassar, 20 Februari 2013. 